\title{
Peningkatan Pengetahuan Masyarakat Dalam Deteksi Kanker Serviks Dan Payudara Di Desa Ringinharjo
}

\author{
Alfun Dhiya An", Alfaina Wahyuni², Nur Hayati³ \\ 1 Ilmu Kebidanan dan Kandungan Fakultas Kedokteran dan IImu Kesehatan, Universitas Muhammadiyah Yogyakarta \\ 2 Ilmu Kebidanan dan Kandungan Fakultas Kedokteran dan Ilmu Kesehatan, Universitas Muhammadiyah Yogyakarta \\ 3 Radiologi Fakultas Kedokteran dan Ilmu Kesehatan, Universitas Muhammadiyah Yogyakarta \\ Email: alfundhiyaan@fkik.umy.ac.id \\ DOI: $10.18196 / \mathrm{ppm} \cdot 36.315$
}

\begin{abstract}
Abstrak
Data Kesehatan Provinsi DIY tahun 2016 menunjukkan angka kejadian kanker serviks di Kota Yogyakarta sebanyak 341 kasus, Kabupaten Sleman sebanyak 962 kasus, Kabupaten Gunung Kidul sebanyak 105 kasus, Kabupaten Kulon Progo sebanyak 205 kasus, dan terbanyak di Kabupaten Bantul sebanyak 1.355 kasus. Kegiatan pengabdian Masaraat ini bertujuan untuk meningkatkan pengetahuan mengenai Deteksi Dini Kanker Serviks dan Payudara. Mitra kegiatan ini adalah Ibu-ibu kader di Desa Ringinharjo, Bantul. Dilaksanakan pada hari Minggu, 13 September 2020 yang dibagi menjadi dua sesi yaitu pada jam 08.30-10.30 dan jam 10.30-12.30. Metode yang digunakan adalah ceramah secara langsung kepada total 34 orang ibu-ibu kader dengan materi berupa pengetahuan tentang kanker serviks, kanker payudara, dan tumor organ reproduksi yang didahului dengan pretest dan posttest pada akhir kegiatan dalam bentuk kuesioner. Kegiatan ini dilakukan dengan tetap memperhatikan protokol kesehatan guna mencegah penyebaran covid-19. Selanjutnya hasil pretest tentang pengetahuan kanker serviks $71 \%$, dan hasil rerata posttest $80 \%$ yang mana dari hasil tersebut menunjukkan adanya peningkatan pengetahuan sebanyak 9\%. Sedangkan rerata pretest tentang pengetahuan kanker payudara $63 \%$, dan hasil rerata posttest $76 \%$. Sehingga dari hasil tersebut adanya peningkatan pengetahuan sebanyak $13 \%$. Kegiatan ini diakhiri dengan pemeriksaan USG gratis untuk ibu-ibu kader yang hadir.
\end{abstract}

Kata Kunci: perempuan, kanker serviks, kanker payudara

\section{Pendahuluan}

Angka kejadian kasus baru kanker serviks di negara berkembang diperkirakan tiga kali lipat dari negara maju. Menurut WHO, di Indonesia kanker serviks menempati urutan kedua setelah kanker payudara. Didapatkan kasus baru kanker serviks sekitar 20.928 dan kematian akibat kanker serviks dengan persentase 10,3\% (WHO, 2014). Berdasarkan masalah yang ada, timbul gagasan untuk melakukan skrining kanker serviks dengan metode yang lebih sederhana, antara lain yaitu dengan IVA (Inspeksi Visual dengan Asam Asetat). IVA adalah pemeriksaan skrining kanker serviks dengan cara inspeksi visual pada serviks dengan apli kasi asam asetat (IVA). Dengan metode inspeksi visual yang lebih mudah, lebih sederhana, lebih mampu laksana, maka skrining dapat dilakukan dengan cakupan lebih luas, diharapkan temuan kanker serviks dini akan bisa lebih banyak. Kemampuan tersebut telah dibuktikan oleh berbagai penelitian.

Data Kesehatan Provinsi DIY tahun 2016 menunjukkan angka kejadian kanker serviks di Kota Yogyakarta sebanyak 341 kasus, Kabupaten Sleman sebanyak 962 kasus, Kabupaten Gunung Kidul sebanyak 105 kasus, Kabupaten Kulon Progo sebanyak 205 kasus, dan terbanyak berada di Kabupaten Bantul sebanyak 1.355 kasus (Dinas Kesehatan DIY, 2016). Data dari Seksi Pengendalian Penyakit tahun 2016 angka capaian deteksi dini kanker serviks melalui metode Inspeksi Visual Asam asetat (IVA) yang dilakukan oleh Dinas Kesehatan DIY, jumlah capaian rata-rata adalah $17,71 \%$ serta yang menduduki peringkat tertinggi adalah Kota Yogyakarta yaitu 46,83\%, 27,99\% di Kabupaten Kulon Progo, 9,47\% di Kabupaten 
Sleman, 9,42 di Kabupaten Gunung Kidul, dan terendah 9,03\% berada di Kabupaten Bantul (Seksi P2 Dinkes DIY, 2017). Dari data tersebut tampak bahwa meskipun kejadian kanker serviks di Kabupaten Bantul cukup tinggi, akan tetapi cakupan pemeriksaan IVA masih rendah.

Dari studi pendahuluan yang dilakukan di Desa Ringinharjo Kecamatan Bantul dengan wawancara diperoleh informasi bahwa masyarakat masih banyak yang belum mengetahui tentang kanker serviks secara menyeluruh dan masih rendahnya kesadaran masyarakat untuk melakukan IVA secara mandiri. Solusi yang ditawarkan dalam pengabdian ini yaitu peningkatan pemahaman ibu tentang keganasan organ reproduksi dalam rangka peningkatan self awareness mereka dan peran serta ibu ibu dalam deteksi dini kanker serviks dengan metode IVA.

\section{Metode Pelaksanaan}

Langkah - langkah yang ditempuh guna melaksanakan solusi atas permasalahan spesifik yang dihadapi mitra adalah sebagai berikut:

1. Melakukan koordinasi dengan pihak mitra untuk membahas kegiatan yang akan dilakukan sehingga selaras dengan program kerja puskesmas mitra. Pembahasan sampai kepada teknis pelaksanaan berikut jadwal dan tempat kegiatan. Termasuk di dalamnya menentukan penanggungjawab tiap kegiatan baik dari unsur mitra dan tim pengabdi.

2. Melakukan penilaian secara kuantitatif tingkat pemahaman bidan, kader kesehatan, ibu hamil dan keluarganya dengan membagikan kuesioner sebelum dan sesudah pemberian materi dan pemeriksaan IVA. Kuesioner disusun oleh tim pengabdi dan sudah mendapat persetujuan dari mitra. Kuesioner dikuantitatifkan sehingga didapatkan nilai pretest dan posttest. Peningkatan nilai pretest dan posttest digunakan sebagai salah satu indicator pencapaian kegiatan.

3. Melakukan pemeriksaan IVA test pada ibu ibu sasaran.

4. Evaluasi Kegiatan dan Rencana Tindak lanjut sehingga program selalu berkelanjutan

\section{Hasil dan Pembahasan}

\section{Profil Responden}

Profil responden dalam pengabdian ini meliputi usia responden. Adapun hasilnya adalah sebagai berikut:

\begin{tabular}{|lc|}
\multicolumn{2}{|c|}{ Tabel 1. Profil Responden Seminar } \\
\hline Umur & $\mathbf{N}$ \\
\hline$\leq 30$ tahun & $\mathbf{3}$ \\
\hline $\mathbf{3 1}-\mathbf{4 0}$ tahun & 19 \\
\hline$>41$ tahun & 12 \\
\hline \hline Jumlah & 34 \\
\hline
\end{tabular}

Tabel di atas menunjukkan bahwa sebagian besar responden berumur $31-40$ tahun, yaitu 19 responden dan paling sedikit berumur $<30$ tahun, yaitu 2 responden.

\section{Deskripsi Pengetahuan tentang Kanker Serviks dan Kanker Payudara Sebelum Seminar}


Tingkat pengetahuan tentang kanker serviks dan kanker payudara sebelum seminar, dapat dideskripsikan sebagai berikut:

Tabel 2. Distribusi Frekuensi Pengetahuan tentang Kanker Serviks Sebelum Seminar

\begin{tabular}{l|cc} 
Kategori & Skor & N \\
Baik & $>80$ & 8 \\
Sedang & $70-80$ & 15 \\
Tidak Baik & $<70$ & 11 \\
\cline { 2 - 2 } Total & & 34 \\
\hline \multicolumn{2}{r|}{} \\
\hline
\end{tabular}

Tabel 2 menunjukkan bahwa sebelum seminar, sebagian besar responden mempunyai pengetahuan tentang kanker serviks kategori sedang, yaitu 15 dan paling sedikit kategori baik, yaitu 8 responden.

\begin{tabular}{|c|c|c|}
\hline \multicolumn{3}{|c|}{ Sebelum Seminar } \\
\hline Kategori & Skor & $\mathbf{N}$ \\
\hline Baik & $>80$ & 3 \\
\hline Sedang & $70-80$ & 6 \\
\hline Tidak Baik & $<70$ & 25 \\
\hline \multicolumn{2}{|c|}{ Total } & 34 \\
\hline
\end{tabular}

Tabel 3 menunjukkan bahwa sebelum seminar, sebagian besar responden mempunyai pengetahuan tentang kanker payudara kategori tidak baik, yaitu 25 dan paling sedikit kategori baik, yaitu 3 responden.

\section{Deskripsi Pengetahuan tentang Kanker Serviks dan Kanker Payudara Sesudah Seminar}

Pengetahuan tentang tentang kanker serviks dan kanker payudara sesudah seminar, dapat dideskripsikan sebagai berikut:

Tabel 4. Distribusi Frekuensi Pengetahuan tentang Kanker Serviksa Sesudah
\begin{tabular}{|l|cc}
\hline Kategori & Skor & N \\
Baik & $>80$ & 15 \\
Sedang & $70-80$ & 17 \\
Tidak Baik & $<70$ & 2 \\
\hline \multicolumn{2}{r|}{ Total } & 34 \\
\hline
\end{tabular}

Tabel 4 menunjukkan bahwa sesudah seminar, sebagian besar responden mempunyai pengetahuan tentang kanker serviks kategori sedang, yaitu 17 dan paling sedikit kategori tidak baik, yaitu 2 responden. 


\begin{tabular}{l|cc|} 
Kategori & Skor & N \\
Baik & $>80$ & 16 \\
Sedang & $70-80$ & 10 \\
\hline Tidak Baik & $<70$ & 8 \\
\hline \multicolumn{2}{r|}{ Total } \\
\hline
\end{tabular}

Tabel 5 menunjukkan bahwa sesudah seminar, sebagian besar responden mempunyai pengetahuan tentang kanker payudara kategori baik, yaitu 16 dan paling sedikit kategori tidak baik, yaitu 8 responden.

\section{Peningkatan Pengetahuan tentang Kanker Serviks dan Kanker Payudara Sebelum dan Sesudah Seminar}

Tabel 6. Hasil Pretest dan Posttest Pengetahuan Kanker Serviks

\begin{tabular}{|lll|}
\hline & Pretest & Posttest \\
\hline Jumlah skor & 2.420 & 2.740 \\
\hline Rata-rata & $71 \%$ & $80 \%$ \\
\hline
\end{tabular}

Tabel 6 menunjukkan bahwa hasil pretest dan posttest peserta menunjukkan adanya peningkatan, dengan hasil rerata pretest tentang pengetahuan kanker serviks $71 \%$, dan hasil rerata posttest $80 \%$ yang mana dari hasil tersebut menunjukkan adanya peningkatan pengetahuan sebanyak $9 \%$.

Tabel 7. Hasil Pretest dan Posttest Kanker Payudara

\begin{tabular}{|lll|} 
& Pretest & Posttest \\
\hline Jumlah skor & 2.175 & 2.593 \\
\hline Rata-rata & $63 \%$ & $76 \%$ \\
\hline
\end{tabular}

Tabel 7 menunjukkan bahwa rerata pretest tentang pengetahuan kanker payudara $63 \%$, dan hasil rerata posttest $76 \%$. Berdasar dari hasil tersebut terjadi peningkatan pengetahuan sebanyak $13 \%$.

\section{Simpulan}

Berdasarkan hasil pengabdian yang telah dilakukan tentang pengetahuan dan upaya deteksi dini serviks dan kanker payudara pada wanita di Desa Ringinharjo Kecamatan Bantul, maka dapat ditarik simpulan bahwa pengetahuan responden tentang kanker serviks sebelum seminar $71 \%$ dan sesudah seminar $80 \%$. Sedangkan pengetahuan responden tentang kanker payudara sebelum seminar $63 \%$ dan sesudah seminar $76 \%$. Terdapat peningkatan pengetahuan tentang kanker serviks dan kanker payudara sebelum dan sesudah seminar.

\section{Ucapan Terima Kasih}

Ucapan terima kasih kami tujukan terutama kepada pemberi dana LP3M UMY. Ucapan terima kasih juga kami tujukan kepada mitra kerjasama yakni segenap kader di Desa Ringinharjo yang telah mengikuti seminar, serta semua kerabat kerja yang turut membantu dalam terlaksananya program pengabdian ini. 


\section{6}

\section{Daftar Pustaka}

Dinas Kesehatan Provinsi Yogyakarta, 2016, Profil Kesehatan Provinsi Yogyakarta 2016, Yogyakarta: Dinkes Provinsi Yogyakarta.

Dinas Kesehatan Provinsi Yogyakarta, 2017, Profil Kesehatan Provinsi Yogyakarta 2017, Yogyakarta: Dinkes Provinsi Yogyakarta 